\title{
E-Commerce Readiness to Support SMEs in Tourism Area: Case of North Sumatera
}

\author{
Arlina Nurbaity Lubis ${ }^{1}$, Prihatin Lumbanraja ${ }^{2}$ and Beby Kendida Hasibuan ${ }^{3}$ \\ $\left\{\right.$ arlina@usu.ac.id ${ }^{1}$ \} \\ ${ }^{1,2,3}$ Faculty of Economic and Business, Universitas Sumatera Utara, Medan, Indonesia
}

\begin{abstract}
A successful tourism required the support from SMEs that affiliated with the tourism area. Today's revolution industry 4.0 forced much more digitized and internetization of SMEs in near future. The existence of advanced technologies lead to application of e-commerce. The future of SMEs' growth will be driven with e-commerce. This paper aimed to evaluate the e-commerce adoption readiness from SMEs in Tourism Area. E-commerce will improve overall business which may also promote tourism in the future. A number of 200 SMEs were participated in this study. The SMEs' were collected from four main area of toursm, the lake, mountain, coastal and city tour. A spiderweb were used to ease presentation of our study. The result indicate that Medan has the most advanced SMEs to adopt e-commerce. The greatest hurdle to other areas were their infrastructures and their adaptation toward technologies.
\end{abstract}

Keywords: E-Commerec, Technology Adaptation, Management, Tourism, North Sumatera

\section{Introduction}

Tourism has become the spotlight for Indonesia and has been growing steadily since 2012 (Indonesia Statistics Bureau, 2015). It has become the great source to improve economic development, both for the local society and national as whole. As we talked about tourism, North Sumatera were blessed by many tourism spot such as Toba Lake, especially Samosir Island. North Sumatera also hold many hills and beach tourism spot around the proviciency. It is for a reason North Sumatera selected as one of featured tourism destination in Visit Indonesia Program.

Tourism was not a stand-alone program that can perform well without another aspect. Spillane (1994) argued that tourism at least involved in socio-cultural aspect, economic aspect, and political aspect. Tourism required the existence of many industries to support themselves. Creative industries helped to improve the tourism experience for good (Lumbanraja et al., 2017). Many industries helped to improve tourist's tourism experience in a good way that lead to satisfaction. A satisfied tourist tend to become loyal (Kotler and Keller, 2012) which will shape their behaviour, such as revisited the tourism spot, even recommend their vacation to others in near future.

Tourism is supported by the pillar of economic aspect. A certain ghost town has been fully regenerated by the support of creative industries that reshaped the dying village into tourism spot (Dahm, 1994). Jayne (2004) and Rogerson (2008) also studied the importance of SMEs to support tourism. Both of the previous work focussed on how creative industry support tourism.

As we talked about how SMEs will support tourism, we need to take a note that SMEs also will undergo transformation, the more digitalized and automated industry as descibed in the forth industrial revolition, Industry 4.0. Almada-lobo's work (2016) 
stated that cloud computing and Internet of Things (IoT) will become the core and the driver to stimulate SMEs' growth. SMEs will become more globalized that globalization itself. It will ease the integration for both forward or backward integration (Lubis et al. 2018).

Industry 4.0 will be more likely give most part of opportunities to SMEs. However many of SMEs were not ready to adopt in Industry 4.0 (Shcroder, 2017). The biggest hurdle to overcome to adopt Industry 4.0 was the poorly equipped SMEs in addition to their lack of advanced technology development acceptance behaviour. Still, it is important to evaluate their readiness to accept the change as it will be the source of their future growth (Bettiol et al., 2017).

Rahayu and Day (2017) studied the important factor that affect Indonesia's adaptation toward e-commerce. They conclude that perceived usefulness, technological readiness, innovation, information and technologies exposure, and the owner's experiences were the decesive factor that affect SMEs' readiness to adopt SMEs. Nurrohmah and Alfanur (2016)'s work suggested three factor that affect SMEs' ecommerce adoption which were their technological readiness, external factor, and internal factor. Kabanda and Brown (2017) suggested that technological readiness was the most influental factor.

$\mathrm{Li}$ and Xie (2012) argued that e-commerce related buying and selling products or services through electronic data transmission using the internet, thus it promote easiness and effectiveness in each transaction. E-commerce can also help to promote business, even the tourism as one product. E-commerce will help to promote and stimulate tourism itself.

This study aimed to evaluate the e-commrece readiness in SMEs that support tourism spot. The ultimate goal of this study was to promote and support tourism through the existence of SMEs that readily adapt themselves toward changes.

\section{Literature Review}

\subsection{North Sumatra Tourism Region}

\subsubsection{Lake Tourism Area}

The most famous Lake tourism area in North Sumatra is the Lake Toba Region consisting of Parapat, Lake Toba, and Samosir Island. In this area, the main tourist attractions are scenery, culinary and cultural tourism. Strong cultural values themselves become an attraction for visitors. Even some of the visitors mentioned the Lake Toba area as Mythical Tourism with a unique tourist experience. Industries such as handicrafts (souvenirs), culinary, transportation (crossings), vehicle rental, lodging, and fashion have grown and developed quite well in this area.

\subsubsection{Mountain Tourism Area}

Berastagi is a small highland town located 60 kilometers to the south of Medan. The area can be accessed by taking a mountain path. The temperature in the area is relatively cooler than Medan which makes it very suitable for the fresh fruit and vegetable plantation area. This tourist area has many tourism sectors such as Lumbini Natural Park (Temple), Hot Springs, Hillpark, Mickey Holiday, Wajik Peceren, Berastagi, Sibolangit Campground, and so on. In this tourist area, many fresh fruit 
sellers were found. Industries that have grown and developed include entertainment, lodging, cafes, and the experience of picking fruits from the garden.

\subsubsection{Coastal Tourism Area}

In this area, many business developers use the beach as a basis for building tourist attractions. Since seeing the success of Cermin Beach as a tourist attraction, there are now many beach-based tourism objects that are growing and developing, such as Romance Bay, Mangrove Beach, Bali Lestari Beach, and so on. The industry that grows a lot in this area is the handicraft, rental place, photography, and culinary.

\subsubsection{City Tourism Area}

Medan is the capital of the province of North Sumatra, Indonesia. Medan is also the city center. Medan has the main attraction for visitors because here is the center of all tourism activities, especially as a source of information and access to the tourist area. The city center also has various landmarks that attract tourists. Medan has a lot of attraction that can be a tourism spot, such as the Maimum Palace with its historical and cultural stories; Shopping center for visitors who like shopping; day and night various culinary; Museum; Zoo, and many other interesting attractions. In this city, there are also many centers of developing creative industries that are supported by the advancement of infrastructure that helps smooth business operations of business actors. All types of industries grow and develop in the center of this city such as culinary, advertising, travel, lodging, and so on.

\section{$2.2 \quad$ E-Commerce}

E-commerce is a transaction-level activity of business activities conducted electronically. This includes online marketing, internet banking, online delivery of goods, and transactions without having to face to face (Pease and Rowe, 2003). Pease and Rowe (2003) indicate that e-commerce is a substantial factor in the era of global competition in an effort to achieve business excellence, growth, and sustainability. Savrul et al. (2014) stated that the weakness of the small business size of MSMEs in global competition can be covered by optimal e-commerce applications.

E-commerce activities play an important role in encouraging MSME performance. The study indicates that MSMEs that conduct e-commerce practices have a performance of 1.35 times or 35\% better than MSMEs that do not practice it (Zou and Liu, 2012). However, there are still many MSMEs found not doing the practice. Some obstacles are that there are still many MSMEs that do not care about e-commerce issues. Lack of talent in e-commerce as well as low salary levels in MSMEs encourages low interest in e-commerce experts in the environment of MSMEs themselves (Chen and Zhang, 2015).

\subsection{E-Commerce Readiness from SMEs}

The technological and information era makes business transactions happen quickly, without having to have a face-to-face contact between the seller and the buyer. This makes business happen anywhere and anytime. The Pew Research Center Survey (in Subramanya, 2018) shows that $79 \%$ of the population of the United States is online shoppers, in which $51 \%$ of them make transactions via telephone calls. E-commerce plays an important role in accelerating business transactions and providing convenience for companies and customers. 
Subramanya (2018) stated that readiness in an effective e-commerce adaptations includes four aspect, the inventory management, internet based technologies, consumer behaviour, and business personalization. Mastering these aspects will lead to a better ecommerce adaptation.

\subsubsection{Inventory management}

Mastery of inventory management is the main thing in the readiness to implement e-commerce. E-commerce itself allows access to information and rapid interaction between sellers and buyers. Information accuracy is needed in ensuring customer satisfaction for purchases made. For example, errors in inventory management will give consumers false information. The seller initially states that goods with specifications requested by consumers are available, but due to management errors, the item has been sold and the seller must be responsible for the misinformation.

\subsubsection{Internet-based technology}

Information technology and information systems are important factors in the realization of e-commerce. The momentum of truth from e-commerce occurs with the existence of internet-based technology. Mastery of this technology includes access to online stores, website management, affiliation with suppliers and consumers only through gadgets. All information bases needed in business management are easily obtained through existing technology.

\subsubsection{Analysis of consumer behavior}

Success in the application of e-commerce is also related to the analysis of consumer behavior. E-commerce makes it easy for businesses to analyze consumer behavior based on available sales data. This data can be the basis for making price discount policies, loyalty rewards, or product suggestions to buyers. Therefore, there needs to be fundamental knowledge about consumer behavior so that e-commerce that will be implemented can be used optimally by business peoples.

\subsubsection{Business personalization}

This element invites businesses not to be rigid in their business activities. Business personalization can be done on each consumer based on the data flow that is owned in the e-commerce process. This personalization will attract attention, interest, and generate customer satisfaction.

These four main elements will be the focus of mapping studies conducted on MSMEs in the North Sumatra tourism area. These four elements are keys to the readiness of MSMEs in carrying out e-commerce activities.

\section{RESEARCH METHOD}

\subsection{Research time}

The study was conducted in Medan from April to August 2018. 


\subsection{Participant}

It is common that many of SMEs in North Sumatera were unregistered and there is no a central registry for many of SMEs. This condiditon suggested a use of nonprobability sampling. A number of 50 SMEs around each of tourism area in North Sumatera were taken as sample by using stratified-cluster sampling method. Thus, in total there were 200 SMEs participated in this study. Each of area were taken in 50 SMEs, lake area proxied by Toba Lake, coastal area proxied by Perbaungan, mountain area proxied by Berastagi, and city tour area, proxied by the capital, Medan.

\subsection{Data collection method}

Self-administered questionnaires were employed during our research. Thus, it required a further validity and reliability test before the actual data taken to measure their e-commerce readiness. The questionnaires were taken from literature review and adopted to suit the situation of our sample.

\subsection{Validity and reliability}

Our study conducted validity and realiability test in Medan as it was one of our sampling area. A number of 30 SMEs which would not be taken as further sample participated in this test. The result of validity and reliability test were summarized in Table 1.

Table 1. Validity and Reliability Result

\begin{tabular}{lcccc}
\hline Variable & Item & $\begin{array}{c}\text { Pearson } \\
\text { Correlation }\end{array}$ & $\begin{array}{c}\text { Critical } \\
\text { Value }\end{array}$ & Conclusion \\
\hline$e-$ & commerce \\
readiness & Inventory1 & 0,708 & 0,361 & Valid \\
\cline { 2 - 5 } & Inventory2 & 0,731 & 0,361 & Valid \\
\cline { 2 - 5 } & Inventory3 & 0,724 & 0,361 & Valid \\
\cline { 2 - 5 } & Tech1 & 0,623 & 0,361 & Valid \\
\cline { 2 - 5 } & Tech2 & 0,613 & 0,361 & Valid \\
\cline { 2 - 5 } Tech3 & 0,677 & 0,361 & Valid \\
\cline { 2 - 5 } & Behavior1 & 0,821 & 0,361 & Valid \\
\cline { 2 - 5 } & Behavior2 & 0,757 & 0,361 & Valid \\
\cline { 2 - 5 } Behavior3 & 0,623 & 0,361 & Valid \\
\cline { 2 - 5 } & Personalize1 & 0,601 & 0,361 & Valid \\
\cline { 2 - 5 } & Personalize2 & 0,522 & 0,361 & Valid \\
\cline { 2 - 5 } & Personalize3 & 0,721 & 0,361 & Valid \\
\hline
\end{tabular}

Cronbach's alpha $(\mathrm{n}=12)=0,827$

Table 1 conclude that both validity and reliability criteria were met in our questionnaire. Thus, our instrument were acceptable to be used in the study. We evaluate the validity by using face validity and pearson correlation. The internal consistency were taken as the measurement for reliability.

\subsection{Data analysis method}

The data were analyzed using simple descriptive statistics and group analysis. Spiderweb were used to ease the reader to read the mapping of SMEs' readiness to run e-commerce effectively and efficiently. 


\section{Result And Discussion}

\subsection{Mapping Results}

This study included samples taken by chance (convenience sampling) from each sampling area. There are fifty MSMEs from each region participating in this study with a total sample of two hundred business units. The mapping results in this study are summarized in Table 2.

Table 2. Mapping of E-Commerce Readiness

\begin{tabular}{lccccc}
\hline & \multicolumn{5}{c}{ Average Value } \\
\cline { 2 - 6 } & All & City & Mountain & Coastal & Lake \\
\hline N of Sample & 200 & 50 & 50 & 50 & 50 \\
\hline $\begin{array}{l}\text { Core } \\
\text { Element }\end{array}$ & & & & & \\
\hline $\begin{array}{l}\text { Inventory } \\
\text { Management }\end{array}$ & 3,02 & 3,47 & 2,81 & 2,73 & 3,05 \\
\hline Technologies & 2,86 & 3,81 & 2,33 & 2,48 & 2,80 \\
\hline $\begin{array}{l}\text { Consumer } \\
\text { Behaviour }\end{array}$ & 3,87 & 4,13 & 3,97 & 3,42 & 3,94 \\
\hline Personalized & 3,97 & 3,92 & 4,11 & 3,68 & 4,17 \\
\hline
\end{tabular}

In this study, the core elements of e-commerce readiness to implement act as a single entity, not as separate elements from one another. This confirms that the assessment of the readiness aspect cannot be applied by assessing the general condition (overall aspect), but seeing each aspect separately. For example, if from the aspect of technology readiness, business peoples are still seen to be inadequate (eg score 2.51) and aspects of assessment of consumer behavior are very good (eg score of 5.00); the average operation does not apply which states that in general the business is ready to implement e-commerce. In fact, they cannot apply the technology needed so that the ecommerce process does not work as it should.

Spiderweb is used in describing the condition of e-commerce readiness from industry in the North Sumatra tourism area. The results of the overall analysis are summarized in Figure 1. 


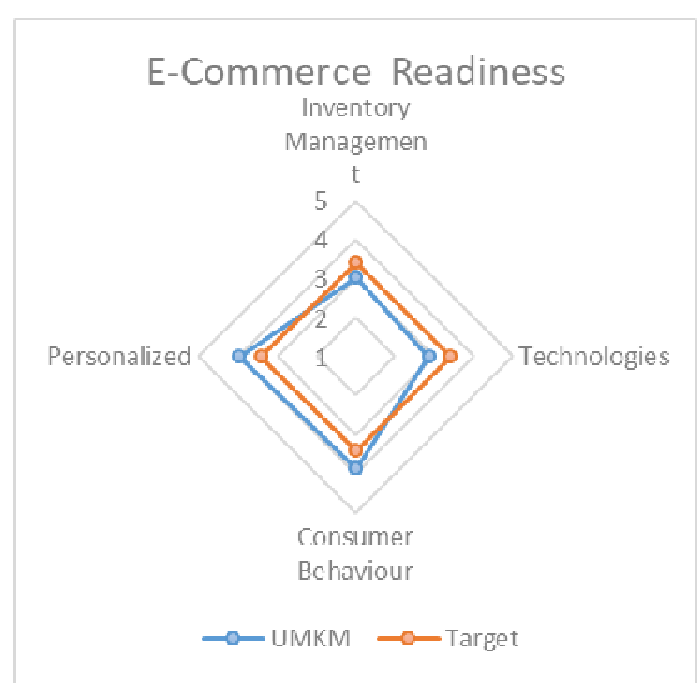

Fig.1. SMEs' E-Commerce Readiness

Figure 1 uses the assumption that the treatment between the situations of each region is considered the same. In these assumptions, in general, MSMEs in North Sumatra already have provisions in implementing e-commerce on aspects of personalizing consumer needs and analyzing consumer behavior. In conducting business operations, even though they have not been confronted with real e-commerce, business people have been able to analyze consumer behavior, even giving consumers discounts to attract the attention of consumers. Based on their experience, business peoples take strategic decisions that can be used to stimulate the intention to buy from potential customers. This condition is found in many street vendors. Bargaining activity is one of the efforts in adjusting the price level to the price that can be accepted by prospective buyers without directing the seller to the point of loss. Nevertheless, there are two other elements that still cannot be controlled by MSMEs in North Sumatra in general. The ability of inventory management and mastery of technology is still not well implemented by businesses. The interview results generally indicate that there is no clear record of supply of supplies from business peoples. Two things that often happen are businesses stating that the item is available to the consumer and then looking for it. Another condition that occurs is that the businessman checks the warehouse until the information can finally be delivered to the consumer. Each of these two situations invites the risk of customer dissatisfaction, inaccurate information and relatively long service delivery when compared to more tidy and orderly inventory management.

The use of technology is another core element that has not been implemented properly by business people. Currently the internet and social media are common things for the community. Constraints on business peoples are the inability to operate optimally owned devices. Many business people cannot use the internet or use devices as a tool of online stores or personal online store management. 


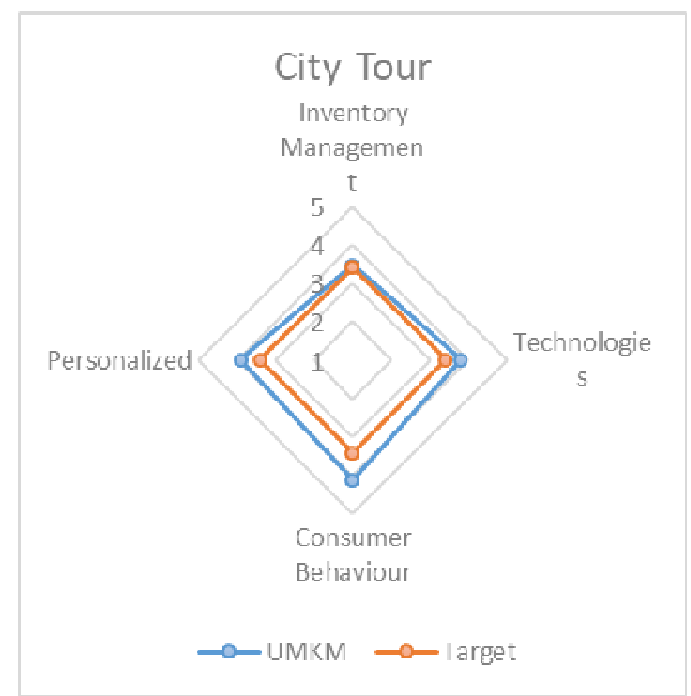

Fig.2. City Tour's E-Commerce Readiness

Figure 2 shows that more specifically, the level of e-commerce readiness in Medan has reached a position that is ready to implement it. Business peoples in Medan are better able and familiar with aspects of technology application, analysis of consumer behavior, personalization of business activities and inventory management. The mapping results indicate that all aspects have met the minimum criteria. This also indicates that partially, business operators in Medan are ready to implement ecommerce in their business activities.

In Medan, this e-commerce activity is already quite active to be carried out by businesses. The presence of an online motorcycle taxi provides many conveniences for businesses in running e-commerce activities. Inventory management is regulated in the application so that it is more easily applied by businesses. In addition, many of the business peoples are end-users in partnership relationships with the online motorcycle taxi system so that they do not need high ability in mastering the application and compiling their own website. Currently e-commerce activities are dominated by the utilization of the partnership relationship. Of the fifty business peoples who were sampled in this study, only $20 \%$ said they had their own online store by utilizing social media. No business actor has a personal website as a business management. 


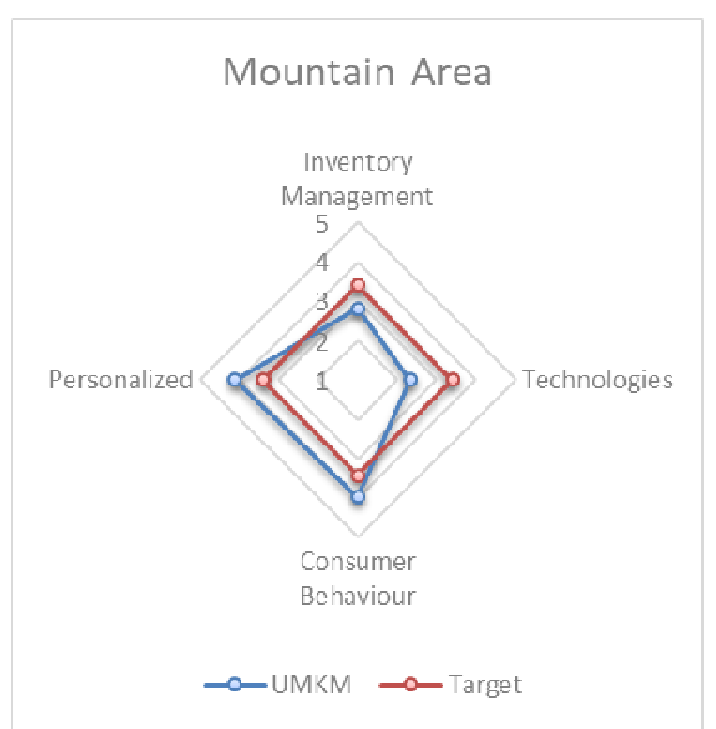

Fig.3. Mountain's E-Commerce Readiness

Figure 3 shows that more specifically, the level of readiness of e-commerce in Berastagi or mountainous areas still cannot be fully implemented given the low technology and inventory management aspects. Based on the results of interviews, the constraints that occur are sourced from inadequate network infrastructure. Many business people state that the internet network in their area feels quite expensive. In addition, there are not many online motorbike accesses that reach the region. Business peoples almost do not carry out inventory management. In and out goods are not controlled as long as they can generate business income.

Figure 4 shows that the level of e-commerce readiness in the surrounding coastal areas indicates a lower level of readiness specifically. Of the four core aspects of ecommerce, the personalization capabilities of business people are slightly better than the criteria. The main problem of this region is the stiffness of the seller's attitude towards the price of the goods offered. For example, the price level of beachfront lodges is very difficult for visitors to offer. They assume that there are many requests from visitors so that the price offered is quite reasonable. In addition, constraints in the use of technology and inventory management are still very lacking from business peoples. 


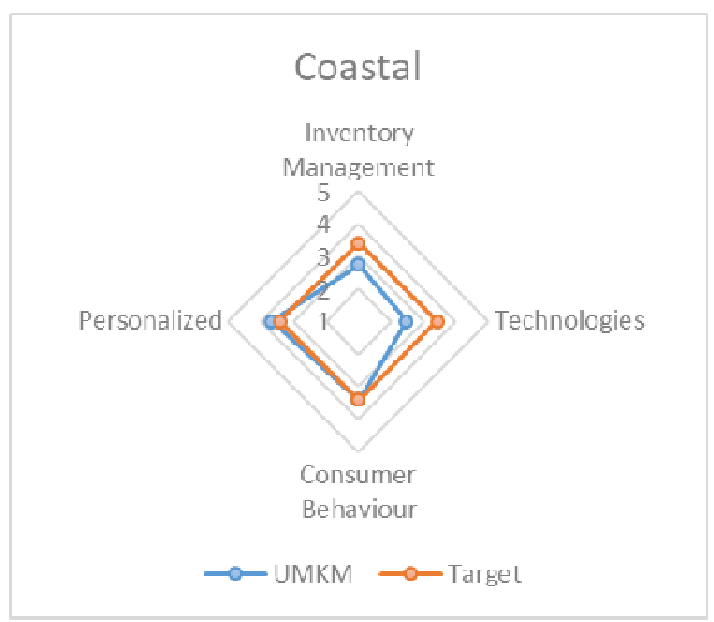

Fig.4. Coastal's E-Commerce Readiness

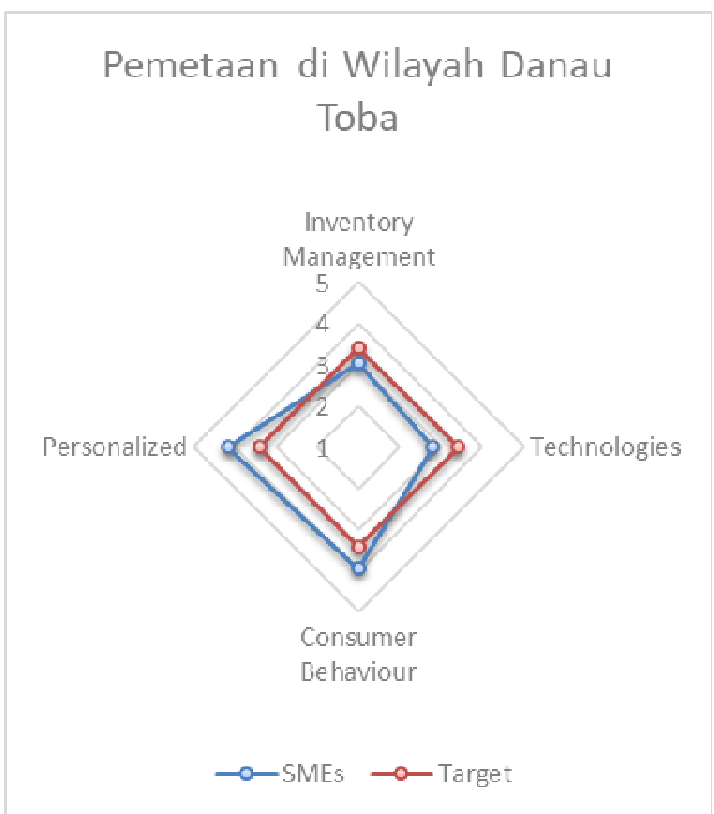

Fig.5. Lake's E-Commerce Readiness

Figure 5 shows that the level of readiness of e-commerce in the Lake Toba area more specifically is still not fully implemented considering the low aspects of technology and inventory management. Business peoples in the region have run their business for a long time so they are used to analyzing consumer behavior and adjusting it to the offer given to these consumers. Technology gaps occur in this region. Many business people are quite familiar with technology, familiarizing themselves with utilizing existing technology; but many also cannot implement the technology. Business peoples in the lodging business category already use google maps and traveloka access 
or similar applications; but other forms of business do not follow the development of these technologies. Improvement in this area needs to be done before e-commerce can be effectively implemented by them.

\section{Conclusions}

In general, e-commerce cannot be implemented effectively and efficiently based on core element mapping. Medan which has been supported by adequate infrastructure is an area that is ready to implement this e-commerce. The main obstacle in the implementation of e-commerce is the readiness of technology and inventory management which is still felt by less than MSMEs in North Sumatra, especially in the tourism sector. Business peoples generally have experience in assessing consumer behavior and making adjustments in an effort to drive the level of sales as part of the basic elements of e-commerce.

Business peoples must be more active in learning and adopting technology and learning how to conduct inventory management. Academics can assist the learning process by holding learning and service activities and lowering students to apprenticeships and mingling with business people by having a positive impact on learning. One of the obstacles to learning is the age of generation. By blending the younger and the old generations, it is hoped that it will be able to encourage the learning process and the technology stutter that occurs.

\section{Acknowledgments}

The authors gratefully acknowledge that the present research is supported by Ministry of Research and Higher Education. The support is under the research grant PTUPT for year 2018

\section{References}

[1] Almada-Lobo, F. (2016). The industry 4.0 revolution and the future of manufacturing execution systems (MES). Journal of Innovation Management, 3(4), pp 16-21

[2] Badan Pusat Statistik, (2015). Perkembangan Pariwisata dan Transportasi Nasional. Jakarta: Badan Pusat Statistik

[3] Bettiol, M., Caprestro, M., di-Maria, E. (2017). Industry 4.0: the Strategic Role of Marketing. Marco Fanno Working Papers - 213

[4] Chen, Q., Zhang, N. (2015). Does E-comerce Provide a Sustained Competitive Advantage? An Investigation of Survival and Sustainability in Growth-Oriented Enterprises. Sustainability, 7, 1411-1428

[5] Dahms, F.A. (1995). Dying villages, counterurbanization and the urban field: A Canadian perspective. Journal of Rural Studies, 11, 21-33

[6] Jayne, M. (2004). Culture that works? Creative industries develompent in a working-class city. Capital \& Class, 199-210

[7] Kabanda, S., Brown, I. (2017). A structuration analysis of Small and Medium Enterprise (SME) adoption of E-Commerce: The case of Tanzania. Telematics and Informatics, 34(4), 118-132. doi: 10.1016/j.tele.2017.01.002.

[8] Kotler, P., Keller, K.L. (2012). Marketing Management. New Jersey: Prentice Hall, 14th Edition 
[9] Li, P., Xie, W. (2012). A strategic framework for determining e - commerce adoption. Journal of Technology Management in China, 7(1), 22-35. doi: 10.1108/17468771211207321.

[10] Lubis, A.N., Lumbanraja, P., Hasibuan, B.K. (2018). Stimulating SMEs performance based on Marketing Mix Approach: A Study of Featured SMEs in Medan, Paper Presented in ICOSTEERR 2018, Medan, Universitas Sumatera Utara

[11] Lumbanraja, P., Lubis, A.N., Hasibuan, B.K. (2017). Creative Industries Readiness to Support Tourism in Danau Toba, Paper Presented in EBIC 2017, Medan, Universitas Sumatera Utara - Atlantis Press

[12] Nurrohmah, A., Alfanur, F. (2016). Adoption of E-Commerce on Micro and Small Enterprise in Bandung (Fashion Subsector Case Study). e-Proceeding of Management, pp. 1120-1127.

[13] Pease, R.W., Rowe, M. (2003). E-commerce and Small Medium Enterprises (SMEs) in Regional Communities, [Online] Researchgate

[14] Rahayu, R. and Day, J. (2017). E-commerce adoption by SMEs in developing countries: evidence from Indonesia. Eurasian Business Review, 7(1), 25-41. doi: 10.1007/s40821-016-0044-6.

[15] Rogerson, C.M. (2006). Creative industries and urban tourism: South African perspectives. Urban Forum, 17, 149-164

[16] Savrul, M., Incekara, A., Sener, S. (2014). The Potential of E-commercefor SMEs in a Globalizing Business Environment, Social and Behavioral Sciences $150,35-45$

[17] Schroder, C. (2017). The Challenges of Industry 4.0 for Small and Medium-sized Enterprises, FRIEDRICH-EBERT-STIFTUNG 2015-2017 Project

[18] Spillane, J. (1994). Pariwisata Indonesia (Siasat Ekonomi dan Rekayasa Kebudayaan), Yogyakarta: Kanisius

[19] Zou, Z.X., dan Liu, J. 2012. The Development Strategy of E-commerce in SMEs. Enterprise Economics, 12, 89-90 